\title{
DIFFERENCES BETWEEN CHILDREN WITH EARLY CHILDHOOD CARIES AND CARIES FREE CHILDREN IN ORAL HEALTH HABITS: A CASE CONTROL STUDY
}

\author{
Yosra A. Hussein ${ }^{\prime} B D S$, Magda M. El-Tekeya ${ }^{2} P h D$, Karin L. Dowidar ${ }^{2} P h D$, MahaEl Tantawi ${ }^{3} P h D$
}

\begin{abstract}
INTRODUCTION: Early Childhood Caries (ECC) is a multifactorial disease and has numerous biological, psychological and behavioral factors. It is a significant public health problem with consequences for the growth and development of affected children

OBJECTIVES: The aim of the study was to assess differences between children with early childhood caries and caries free children in socioeconomic background, previous dental visits, oral hygiene practices and dietary habits.

MATERIALS AND METHODS: Parents responded to a questionnaire about children's background (age, sex, parental occupation and education and birth rank), in addition to previous dental visits, nursing history, tooth brushing frequency, use of fluoridated toothpaste, parental supervision of brushing and dietary habits (snack type, frequency and daily quantity). Clinical examination assessed caries using World Health Organization criteria and plaque using Loe and Silness Plaque index. The sample consisted of 84, 4-5-year-old children who visited the pediatric dentistry clinic of the Faculty of Dentistry, Alexandria University in 2016. Equal number of cases (children with ECC) and controls (caries free children) were included.

RESULTS: Children with ECC were significantly more likely to be first borne compared to caries free children $(71.4 \%$ and $52.4 \%$, $\mathrm{P}=0.006)$. Previous dental visits were reported in $38.1 \%$ of children with ECC compared to $4.8 \%$ of caries free children $(\mathrm{p}<0.0001)$. Exclusive breast feeding was reported in $83.3 \%$ of children with ECC compared to $59.5 \%$ of caries free children ( $\mathrm{p}=0.02)$. Plaque index in children with ECC was significantly higher $(0.70 \pm 0.53)$ than that of caries free children $(0.39 \pm 0.50, p=0.001)$.

CONCLUSIONS: Being first borne, history of previous dental visits, exclusive breast feeding and high plaque index were factors that differed significantly between children with ECC and caries free children.

KEYWORDS: preschool children, early childhood caries, plaque, oral health habits.

1- Faculty of Dentistry, Alexandria University, Egypt. Resident, Department of Dentistry, Medical Research Institute, Alexandria University, Egypt.
2- Professor of Pediatric Dentistry, Department of Pediatric Dentistry and Dental Public Health, Faculty of Dentistry, Alexandria University, Egypt.
3- Professor of Dental Public Health, Department of Preventive Dental Sciences, College of Dentistry, University of Dammam, Saudi Arabia.
\end{abstract}

\section{INTRODUCTION}

Early childhood caries (ECC) has been defined as the presence of one or more decayed (non-cavitated or cavitated), missing (due to caries), or filled tooth surfaces in any primary tooth in a child 71 months of age or younger (1).

It is a serious public health problem in both developing and industrialized countries (2). Its consequences can affect the immediate and long-term quality of life of the child and family, and can have significant social and economic effects beyond the immediate family as well (3).

The term "early childhood caries" was suggested to focus attention on the multiple socioeconomic, behavioral, and psychosocial factors that contribute to caries at such early age, rather than ascribing sole causation to inappropriate feeding methods (4).Various risk factors such as feeding pattern (5), early transmission of streptococcus mutans (6), frequency of carbohydrate consumption (7), poor oral hygiene (8),parent's educational level (9), and mother's working status(10) have been studied in relation to ECC.

Abdel Aziz et al showed that drinking juices was associated with less ECC and severe early childhood caries(S-ECC). Snacking on sweets was associated with more S-ECC. Healthy eating, brushing, and bacterial counts were not significantly associated with ECC or S-ECC in multivariate regression (11).

Because of the scarcity of literature on factors associated with ECC among Egyptian preschoolers, the current study was designed to assess the indicators that differ between children with ECC and caries free children including nonmodifiable factors(age, sex, parental occupation and education and birth rank), and modifiable factors(previous dental visits, nursing history, oral hygiene practices, and snacking habits). The hypothesis to be tested in the study was that there would be significant differences between children with ECC and caries free children in these factors.

\section{MATERIALS AND METHODS}

Study design and setting

This case-control study was conducted in the clinic of the Department of Pediatric Dentistry and Dental Public Health, Faculty of Dentistry, Alexandria University and in public nursery schools in Alexandria.

\section{Ethical Considerations}

Ethical approval for the study was obtained from the Dental Research Ethics Committee, Faculty of Dentistry, Alexandria University. Parents were asked to sign an informed consent after explanation of the study purpose.

\section{Study Sample}

Sample size was estimated based on the following assumptions: alpha error $=5 \%$, power $=80 \%$, mean plaque score in children with ECC and caries free children=1.01 and 0.69 , standard deviation $=0.5$ (based on pilot study conducted on 20 children in the paediatric dentistry clinic in the Faculty). The needed number of children per group= 39 (http://powerandsamplesize.com/Calculators/Compare2-Means/2-Sample-Equality). This number was increased to 41 to make up for $5 \%$ estimated non response to the questionnaire. The study included children with ECC and 42 caries free children matched for age and gender. Clinical examination was conducted to select children with ECC and Caries free using a plane mirror and dental 
explorer under daylight without drying according to the World Health Organization (WHO) criteria (12)._To ensure the consistency of caries examination, ten children not included in the study were examined then re-examined after one week. Comparison of the results was assessed by Kappa statistic and it was equal to 0.85 . Children were included in the study if they were 4-5 years old, and healthy (without systemic disease; ASA I physical status) (13).

\section{Data Collection}

Data were collected from parent's/care givers using a structured questionnaire that assessed demographic data (age, gender, birth rank, parental occupation and education), previous dental visits, oral hygiene habits (brushing, frequency of brushing, use of fluoridated toothpaste, parental supervision of brushing), nursing history (breast, bottle or mixed feeding) and snacking habits (snack type, frequency, daily quantity).

\section{Clinical examination}

Silness and Loe Plaque index was used to assess plaque at the gingival area of index teeth. Each of the buccal, lingual, mesial and distal surfaces was given a score from $0-3$. The scores were averaged to give the plaque index of the tooth and those of index teeth were averaged to give the score of the child (14).

\section{STATISTICAL ANALYSIS}

Children with ECC and caries free children were compared regarding sociodemographic factors, oral health practices, dietary habits using $\mathrm{t}$ test, chi square and Mann Whitney $\mathrm{U}$ tests. Significant level was set at 5\%. SPSS version 17.0 was used for statistical analysis.

\section{RESULTS}

The study included 42 children with ECC and 42 caries free children. No statistically significant differences existed between the two groups as regard age or gender $(\mathrm{P}=0.35$ and 0.51 respectively, Table 1). Children with ECC were more likely to be first borne (71.4\%) compared to caries free children $(52.4 \%, \mathrm{P}=0.006)$. No statistically significant differences existed between the two groups as regard mother's education $(p=0.21)$, mother's occupation $(p=0.07)$, father's education $(p=0.37)$ or father's occupation $(\mathrm{p}=0.89)$. The mean (SD) dmf of children with ECC was 5.4 (4.2). A higher percentage of children with ECC were reported to visit the dentist previously than caries free children $(38.1 \%$ and $4.8 \%, \mathrm{P}<0.0001)$. Tooth brushing was reported in $59.5 \%$ of children with ECC and $64.3 \%$ of caries free children $(p=0.65)$. Most children with ECC and caries free children were reported to use fluoridated toothpaste (92\% and $96.3 \%, \mathrm{p}=0.37$ ).

Exclusive breast feeding was reported in $83.3 \%$ of children with ECC compared to $59.5 \%$ of caries free children $(p=0.02$, Table 3$)$. No statistically significant differences existed in the use of sticky snacks $(\mathrm{p}=0.38)$, quantity of sticky snacks ( $\mathrm{p}=0.51)$, use of sweetened juices $(\mathrm{p}=0.38)$, quantity of sweetened juices $(\mathrm{p}=0.73)$ or frequency of sweetened juices $(\mathrm{p}=0.12)$.

The mean plaque index in children with ECC was significantly higher $(0.70)$ than that of caries free children (0.39, $\mathrm{p}=0.001$, Table 4).
Table 1: Sociodemographic background of children with ECC and caries free children.

\begin{tabular}{|c|c|c|c|c|}
\hline & & $\begin{array}{c}\text { Children } \\
\text { with } \\
\text { ECC }\end{array}$ & $\begin{array}{c}\text { Caries } \\
\text { free } \\
\text { Children }\end{array}$ & $\begin{array}{c}\mathbf{P} \\
\text { value }\end{array}$ \\
\hline \multirow{2}{*}{ Age } & Min- $\max$ & $4-5$ & $4-5$ & \multirow{2}{*}{0.35} \\
\hline & Mean (SD) & $4.5(0.4)$ & $4.4(0.4)$ & \\
\hline \multirow{2}{*}{ Gender } & Male: n (\%) & $18(42.9)$ & $21(50)$ & \multirow{2}{*}{0.51} \\
\hline & Female: n (\%) & $24(57.1)$ & $21(50)$ & \\
\hline \multirow{3}{*}{ Birth rank } & $1^{\text {st. }}: n(\%)$ & $30(71.4)$ & $22(52.4)$ & \multirow{3}{*}{$0.006^{*}$} \\
\hline & $2^{\text {nd }}: n(\%)$ & $3(7.1)$ & $15(35.7)$ & \\
\hline & $\begin{array}{l}3^{\text {rd }} \text { and more: } n \\
(\%)\end{array}$ & $9(21.4)$ & $5(11.9)$ & \\
\hline \multirow{3}{*}{$\begin{array}{l}\text { Mother's } \\
\text { education }\end{array}$} & Illiterate: n (\%) & $10(23.8)$ & $4(9.5)$ & \multirow{3}{*}{0.21} \\
\hline & Middle: n (\%) & $15(35.7)$ & $17(40.5)$ & \\
\hline & High: n (\%) & $17(40.5)$ & $21(50)$ & \\
\hline \multirow{2}{*}{$\begin{array}{l}\text { Mother's } \\
\text { occupation }\end{array}$} & $\begin{array}{l}\text { Housewife: } \mathrm{n} \\
(\%)\end{array}$ & $36(85.7)$ & $29(69)$ & \multirow[t]{2}{*}{0.07} \\
\hline & Working: n (\%) & $6(14.3)$ & $13(31)$ & \\
\hline \multirow{3}{*}{$\begin{array}{l}\text { Father's } \\
\text { education }\end{array}$} & Illiterate: n (\%) & $8(19)$ & $4(9.5)$ & \multirow{3}{*}{0.37} \\
\hline & Middle: n (\%) & $17(40.5)$ & $16(38.1)$ & \\
\hline & High: n (\%) & $17(40.5)$ & $22(52.4)$ & \\
\hline \multirow{3}{*}{$\begin{array}{l}\text { Father's } \\
\text { occupation }\end{array}$} & $\begin{array}{l}\text { Professional: } \mathrm{n} \\
(\%)\end{array}$ & $21(50)$ & $20(47.6)$ & \multirow{3}{*}{0.89} \\
\hline & Clerical: n (\%) & $11(26.2)$ & $13(31)$ & \\
\hline & Laborer: n (\%) & $10(23.8)$ & $9(21.4)$ & \\
\hline
\end{tabular}

*: Statistically significant at $\mathrm{P} \leq 0.05$

Table 2: Oral health practices of children with ECC and caries free children.

\begin{tabular}{|c|c|c|c|c|}
\hline & & $\begin{array}{c}\text { Children } \\
\text { with } \\
\text { ECC } \\
\end{array}$ & $\begin{array}{c}\text { Caries } \\
\text { free } \\
\text { Children } \\
\end{array}$ & $P$ value \\
\hline \multirow{2}{*}{$\begin{array}{l}\text { Previous } \\
\text { dental } \\
\text { visits } \\
\end{array}$} & $\begin{array}{l}\text { Yes: } n \\
(\%)\end{array}$ & $16(38.1)$ & $2(4.80)$ & \multirow[t]{2}{*}{$<0.0001 *$} \\
\hline & No: $n(\%)$ & $26(61.9)$ & $40(95.2)$ & \\
\hline \multirow{2}{*}{ Brushing } & $\begin{array}{l}\text { Yes: } n \\
(\%)\end{array}$ & $25(59.5)$ & $27(64.3)$ & \multirow{2}{*}{0.65} \\
\hline & No: $n(\%)$ & $17(40.5)$ & $15(35.7)$ & \\
\hline \multirow{3}{*}{$\begin{array}{l}\text { Brushing } \\
\text { frequency }\end{array}$} & $\begin{array}{l}\text { Once } \\
\text { daily }\end{array}$ & $16(64)$ & $17(62.9)$ & \multirow{3}{*}{0.90} \\
\hline & $\begin{array}{l}\text { Twice } \\
\text { daily }\end{array}$ & $5(20)$ & $5(18.5)$ & \\
\hline & $\begin{array}{l}\text { More } \\
\text { than } \\
\text { twice } \\
\text { daily }\end{array}$ & $4(16)$ & $5(18.5)$ & \\
\hline \multirow{2}{*}{$\begin{array}{l}\text { Using } \\
\text { fluoridated } \\
\text { toothpaste }\end{array}$} & $\begin{array}{l}\text { Yes: } \mathrm{n} \\
(\%)\end{array}$ & $23(92)$ & $26(96.3)$ & \multirow{2}{*}{0.37} \\
\hline & No: $n(\%)$ & $2(8)$ & $1(3.7)$ & \\
\hline \multirow{2}{*}{$\begin{array}{l}\text { Parental } \\
\text { supervision } \\
\text { of } \\
\text { brushing }\end{array}$} & $\begin{array}{l}\text { Yes: } n \\
(\%)\end{array}$ & $21(84)$ & $21(77.77)$ & \multirow{2}{*}{0.83} \\
\hline & No: n $(\%)$ & $4(16)$ & $6(22.22)$ & \\
\hline
\end{tabular}

*: Statistically significant at $\mathrm{P} \leq 0.05$

\section{DISCUSSION}

The results of the current study support the hypothesis that there were significant differences between children with ECC and caries free children in relation to some of the studied caries risk indicators.

In the present case-control study, there was no significant difference between the two groups concerning age or gender proving that the groups were correctly matched. Age is the factor most reported to be associated with ECC (15). The higher the age, the higher the dental caries level (16). Several studies report that gender is not a risk indicator for 
ECC (17), but there are also studies which report the ECC is more prevalent in girls (18).

Table 3: Dietary habits of children with ECC and caries free children.

\begin{tabular}{|c|c|c|c|c|}
\hline & & $\begin{array}{c}\text { Children } \\
\text { with ECC }\end{array}$ & $\begin{array}{c}\text { Caries } \\
\text { free } \\
\text { children }\end{array}$ & $\begin{array}{c}P \\
\text { value }\end{array}$ \\
\hline & $\begin{array}{l}\text { Breast: } n \\
(\%)\end{array}$ & $35(83.3)$ & $25(59.5)$ & \\
\hline $\begin{array}{l}\text { Nursing } \\
\text { history }\end{array}$ & $\begin{array}{l}\text { Bottle: } n \\
(\%)\end{array}$ & $2(4.8)$ & $11(26.2)$ & $0.02 *$ \\
\hline & $\begin{array}{l}\text { Mixed: } n \\
(\%)\end{array}$ & $5(11.9)$ & $6(14.3)$ & \\
\hline Using sticky & $\begin{array}{l}\text { Yes: } n \\
(\%)\end{array}$ & $22(52.4)$ & $18(42.9)$ & \\
\hline snacks & $\begin{array}{l}\text { No: } n \\
(\%)\end{array}$ & $20(47.6)$ & $24(57.1)$ & 0.38 \\
\hline $\begin{array}{l}\text { Quantity of } \\
\text { sticky } \\
\text { snacks }\end{array}$ & $\begin{array}{l}\text { Mean } \\
\text { (SD) }\end{array}$ & $4.3(2.9)$ & $3.8(2.1)$ & 0.51 \\
\hline Using & $\begin{array}{l}\text { Yes: } n \\
(\%)\end{array}$ & $20(47.6)$ & $16(38.1)$ & \\
\hline $\begin{array}{l}\text { sweetened } \\
\text { juices }\end{array}$ & $\begin{array}{l}\text { No: } n \\
(\%)\end{array}$ & $22(52.4)$ & $26(61.9)$ & 0.38 \\
\hline $\begin{array}{l}\text { Quantity of } \\
\text { sweetened } \\
\text { juices }\end{array}$ & $\begin{array}{l}\text { Mean } \\
\text { (SD) }\end{array}$ & $3.6(2.3)$ & $3.8(2.2)$ & 0.73 \\
\hline $\begin{array}{l}\text { Frequency } \\
\text { of sweetened } \\
\text { juices }\end{array}$ & $\begin{array}{l}\text { Mean } \\
\text { (SD) }\end{array}$ & $4.1(3.1)$ & $3.1(2.9)$ & 0.12 \\
\hline
\end{tabular}

*: Statistically significant at $\mathrm{P} \leq 0.05$

Table 4: Plaque index of children with ECC and caries free children.

\begin{tabular}{|l|c|c|}
\hline & $\begin{array}{c}\text { Children with } \\
\text { ECC }\end{array}$ & $\begin{array}{c}\text { Caries free } \\
\text { children }\end{array}$ \\
\hline Mean (SD) & $0.70(0.53)$ & $0.39(0.50)$ \\
\hline Median (range) & $0.56(0,2)$ & $0.17(0,2)$ \\
\hline P value of MWU & \multicolumn{2}{|c|}{$0.001^{*}$} \\
\hline
\end{tabular}

MWU: Mann Whitney U test

*: Statistically significant at $\mathrm{P} \leq 0.05$

Children with ECC were more likely to be the first child among siblings (71.4\%) compared to caries free children $(52.4 \%)$. Nicolau et al (19). Noted that birth rank had a significant association with DMFT. The dmft/DMFT were higher in subjects who were only children compared to other children. However, after adjusting for sex and age, the effect of being an only child was no longer significant. Folayan et al (20) pointed to the importance of birth rank as possible biological factor that may increase the predisposition to caries. Being an only child or a last child was associated with increased caries risk. The higher prevalence of ECC in an only child may be attributed to inadequate information and education about children oral health care among new parents. The importance of first dental visit, diet counselling, and proper oral care methods should be advocated to expectant parents, new parents as well as teachers and caregivers of preschool children.

In our study, $23.8 \%$ of children with ECC had illiterate mothers compared to $9.5 \%$ of caries free children. Kinirons and McCabe (21) reported an ECC prevalence of $40 \%$ in children whose mothers had low levels of education compared to $10 \%$ in children whose mothers had high levels of education. These findings were confirmed by other investigators who reported a strong association between children's oral health and mothers' education (22).

In the present study, there was no significant association between caries and whether mothers worked outside their homes. This agrees with Jabbarifar et al (23) who did not report any significant relation between mother's work status and ECC. However, a strong association was found between mothers' working status and caries in another study (24). Working mothers suffer stress at work; and may have less time to look after their children's oral hygiene.

In the present study, the percentage of those reporting previous dental visits was higher in children with ECC than caries free children. Similarly, Kuriakose et al (25) observed that children with previous dental visits had more caries compared to their peers who did not visit. Also, Nobile et al (26) showed that the prevalence of ECC was significantly higher in those who had visited a dentist in the previous year. This suggests that dentists were contacted only after ECC has occurred and that they do not play an active role in prevention.

In this study, slightly more caries free children reported brushing than those with ECC (64.3\% and 59.5\%). This agrees with Abdel Aziz et al (11) who found that brushing was not significantly associated with ECC or S-ECC. Preschool children may neither understand nor have the manual dexterity to maintain good oral hygiene. This is why parental assistance and guidance in cleaning children's teeth are essential to reduce caries risk.

In the current study, exclusive bottle feeding was reported by $26.2 \%$ of caries free children compared to $4.8 \%$ of children with ECC. The issue of whether bottle feeding is more cariogenic than breastfeeding remains unresolved. Some authors reported that bottle feeding is a risk factor for dental caries, while others did not find such an association (27). Most studies suggest the benefits of breastfeeding for dental caries prevention although two cross-sectional $(28,29)$ and a case-control study $(30)$ did not find significant association.

In the current study there was no significant association between ECC and the use of sticky snacks or sweetened juices. Abdel Aziz et al (11) demonstrated that drinking juices was associated with less ECC and S-ECC. Snacking on sweets was associated with more S-ECC. Kuriakose et al (15) reported a significant association between caries and consumption of in-between meal snacks. Those who consumed snacks three and more times had more carious lesions than those who did not. They recommended limiting snacking time with an emphasis on the quality of snacks.

Plaque index in children with ECC in our study was higher $(0.70 \pm 0.53)$ than that of caries free children $(0.39 \pm 0.50)$. Dental plaque has been related to caries experience among children in previous studies $(31,32)$ including Mohebbiet al (33) who reported an association between ECC and dental plaque (OR=1.5; 95\% CI 1.0-2.3).

The main limitation of this study was the potential for recall bias which is the main threat to case-control studies since information is obtained about past exposures that may not be accurately remembered. However, most of the mothers had no difficulty in recalling the required information.

\section{CONCLUSIONS}

Birth rank as determined by being a first born child, history of previous dental visits, exclusive breast feeding and high 
plaque accumulation seem to be indicators of development of ECC in children.

\section{Recommendations}

Our study emphasizes the role that oral health habits can have on children caries status and points to the role parents should assume in protecting their children against caries. The importance of first dental visit, diet counselling, and proper oral care methods should be advocated to expectant parents, new parents and preschool teachers and caregivers.

\section{CONFLICT OF INTEREST}

The authors declare that they have no conflicts of interest.

\section{REFERENCES}

1. American Academy of Pediatric Dentistry. Policy on early childhood caries (ECC): classifications, consequences, and preventive strategies. Pediatr Dent. 2014; 36:50-2.

2. Livny A, Assali R, SganCohen H. Early childhood caries among a Bedouin community residing in the eastern outskirts of Jerusalem. BMC Public Health. 2007;7:167.

3. Inglehart MR, Filstrup SL, Wandera A. Oral health and quality of life in children. In: Inglehart M, Bagramian R, editors. Oral healthrelated quality of life. Chicago: Quintessence Publishing Co; 2002. pp. 79-88.

4. Schroth RJ, Brothwell DJ, Moffatt ME. Caregiver knowledge and attitudes of preschool oral health and early childhood caries (ECC) Int J Circumpolar Health. 2007;66:153-67.

5. Dini EL, Holt RD, Bedi R. Caries and its association with infant feeding and oral health-related behaviors in 3-4-yearold Brazilian children. Community Dent Oral Epidemiol. 2000; 28:241-8.

6. Berkowitz RJ, Jones P. Mouth to mouth transmission of the bacterium streptococcus mutans between mother and child. Arch Oral Biol. 1985; 30:377-9.

7. Gordon Y, Reddy J. Prevalence of dental caries, patterns of sugar consumption and oral hygiene practices in infancy in S. Africa. Community Dent Oral Epidemiol. 1985; 13:3104.

8. Seow WK, Amaratunge A, Bennett R, Bronsch D, Lai PY. Dental health of aboriginal pre-school children in Brisbane, Australia. Community Dent Oral Epidemiol. 1996; 24:18790.

9. Marino RV, Bomze K, Scholl TO, Anhalt H. Nursing bottle caries: Characteristics of children at risk. ClinPediatr (Phila). 1989; 28:129-31.

10. Tsai AI, Johnsen DC, Lin YH, Hsu KH. A study of risk factors associated with nursing caries in Taiwanese children aged 24-48 months. Int J Paediatr Dent. 2001; 11:147-9.

11. AbdelAziz WE, Dowidar KM, El Tantawi MM. Association of healthy eating, juice consumption, and bacterial counts with early childhood caries. Pediatr Dent. 2015; 37:462-7.

12. World Health Organization. Oral Health Survey. Basic Methods. $4^{\text {th }}$ ed. Geneva, Swizerland: WHO;1997.

13. Saklad M. Grading of patients for surgical procedures. Anesthesiol 1941; 2:281-4. Quoted from: Pasternak LR. Risk assessment in ambulatory surgery. Challenges and new trends. Can J Anesth. 2004;51: R1-5.

14. SilnessJ, Loe H. Periodontal disease in pregnancy II. Corelation between oral hydiene and periodontal condition. ActaOdontolScand. 1964; 22:112-35.

15. Kuriakose $\mathrm{S}$, Joseph E. Caries prevalence and its relation to socio-economic status and oral hygiene practices in 600 preschool children of Kerala-India. J Indian SocPedodPrev Dent. 1999; 17:97-100.

16. Eronat N, Koparal E. Dental caries prevalence, dietary habits, tooth-brushing, and mother's education in 500 urban Turkish children. J Marmara Univ Dent Fac. 1997; 2:599604.

17. Wyne AH, Al-Ghannam NA, Al-Shammery AR, Khan NB. Caries prevalence, severity and pattern in pre-school children. Saudi Med J. 2002; 23:580-4.

18. Lulic-Dukic 0, Juric H, Dukic W, Glavina D. Factors predisposing to early childhood caries (ECC) in children of pre-school age in the city of Zagreb, Croatia. CollAntropol. 2001; 25:297-302.

19. Nicolau B, Marcenes W, Allison P, SheihamA . The life course approach: explaining the association between height and dental caries in Brazilian adolescents. Community Dent Oral Epidemiol. 2005; 33:93-8.

20. Folayan MO, Owotade F, Oziegbe EO, Fadeyibi R. Effect of birth rank on the caries experience of children from a suburban population in Nigeria J Dent Oral Hyg. 2010; 2:27-30.

21. Kinirons M, McCabe M. Familial and maternal factors affecting the dental health and dental attendance of preschool children. Community Dent Health. 1995; 12: 226-9.

22. Szatko F, Wierzbicka M, Dybizbanska E, Struzycka I, Iwanicka-Frankowska E. Oral health of Polish three yearolds and mothers' oral health-related knowledge. Community Dent Health. 2004; 21: 175-80.

23. Jabbarifar SE, Ahmady N, Sahafian SAR, Samei F, Soheillipour S. Association of parental stress and early childhood caries. Dent Res J. 2009; 6: 65-70.

24. Quinonez R, Keels M, Vann W Jr, McIver F, Heller K, Whitt J. Early childhood caries: analysis of psychosocial and biological factors in a high-risk population. Caries Res. 2000; 35: 376-83.

25. Kuriakose S, Prasannan M, Remya KC, Kurian J, Sreejith KR. Prevalence of early childhood caries among preschool children in Trivandrum and its association with various risk factors. ContempClin Dent. 2015; 6: 69-73.

26. Nobile CGA, Fortunato L, Bianco A, Pileggi C, Pavia M. Pattern and severity of early childhood caries in Southern Italy: a preschool-based cross-sectional study.BMC Public Health. 2014; 14:206-18.

27. Avila WM, Pordeus IA, Paiva SM, Martins CC. Breast and bottle feeding as risk factors for dental caries: A systematic review and meta-analysis. PLoS One. 2015;10: e0142922.

28. Perera PJ, Fernando MP, Warnakulasooriya TD, Ranathunga N. Effect of feeding practices on dental caries among preschool children: a hospital based analytical cross sectional study. Asia Pac J ClinNutr. 2014; 23:272-7.

29. Du M, Luo Y, Zeng X, Alkhabit N, Bedi R. Caries in preschool children and its risk factors in 2 provinces in China. Quintessence Int. 2007; 38:143-51.

30. Roberts G, Cleaton-Jones P, Fatti L, Richardson B, Sinwel R, Hargreaves J, et al. Patterns of breast and bottle feeding and their association with dental caries in 1- to 4-year-old South African children. A case control study of children with nursing caries. Community Dent Health. 1994; 11:3841.

31. Sayegh A, Dini EL, Holt RD, Bedi R. Oral health, sociodemographic factors, dietary and oral hygiene practices in Jordanian children. J Dent. 2005; 33:379-88. 
32. Alaluusua S, Malmivirta R. Early plaque accumulation: A sign for caries risk in young children. Community Dent Oral Epidemiol. 1994; 22:273-6.

33. Mohebbi SZ, Virtanen JI, Vahid-Golpayegani M, Vehkalahti MM. Early childhood caries and dental plaque among 1-3-year-olds in Tehran, Iran. J Indian SocPedodPrev Dent. 2006; 24:177-81.

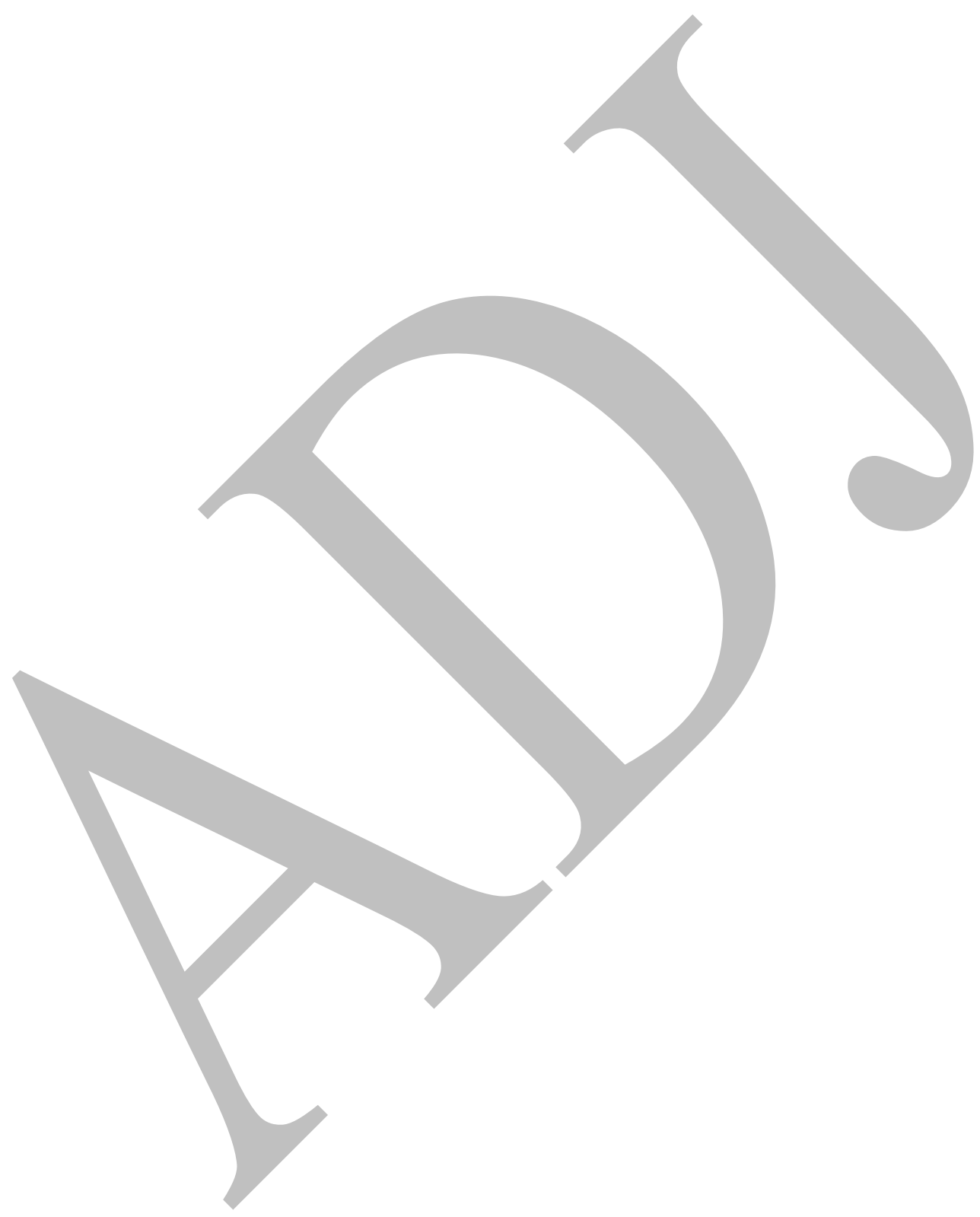

